EPJ Web of Conferences 75, 04010 (2014)

DOI: $10.1051 /$ epjconf/ 20147504010

(C) Owned by the authors, published by EDP Sciences, 2014

\title{
Formation of $\mathrm{Sm}\left(\mathrm{Co}_{1-x} \mathrm{Ni}_{x}\right)_{5}$ epitaxial thin films on $\mathrm{Cu}(111)$ underlayers
}

\author{
Makoto Yamada ${ }^{1, a}$, Takato Yanagawa ${ }^{1}$, Yusuke Hotta ${ }^{1}$, Mitsuru Ohtake ${ }^{1}$, Fumiyoshi Kirino ${ }^{2}$, and Masaaki Futamoto ${ }^{1}$ \\ ${ }^{1}$ Faculty of Science and Engineering, Chuo University, 1-13-27 Kasuga, Bunkyo-ku, Tokyo 112-8551, Japan \\ ${ }^{2}$ Graduate School of Fine Arts, Tokyo University of the Arts, 12-8 Ueno-koen, Taito-ku, Tokyo 110-8714, Japan
}

\begin{abstract}
Sm}_{17}\left(\mathrm{Co}_{1-x} \mathrm{Ni}_{x}\right)_{83}$ (at. \%, $\left.x=0,0.2,0.8,1\right)$ alloy thin films are prepared on $\mathrm{Cu}(111)$ underlayers hetero-epitaxially grown on $\mathrm{MgO}(111)$ substrates by molecular beam epitaxy. The effects of substrate temperature and $\mathrm{Ni} / \mathrm{Co}$ composition on the growth behavior and the detailed resulting film structure are investigated. Formation of $R T_{5}$ ordered phase is enhanced with increasing the substrate temperature and the $\mathrm{Ni}$ composition. The long-range order degrees of $\mathrm{Sm}_{17} \mathrm{Co}_{83}, \mathrm{Sm}_{17}\left(\mathrm{Co}_{0.8} \mathrm{Ni}_{0.2}\right)_{83}, \mathrm{Sm}_{17}\left(\mathrm{Co}_{0.2} \mathrm{Ni}_{0.8}\right)_{83}$, and $\mathrm{Sm}_{17} \mathrm{Ni}_{83}$ films deposited at $500{ }^{\circ} \mathrm{C}$ are estimated to be $0.77,0.82,0.89$, and 0.97 , respectively. The $\mathrm{Sm}_{17}\left(\mathrm{Co}_{1-x} \mathrm{Ni}_{x}\right)_{83}$ films with $R T_{5}$ structure consist of two types of epitaxial (0001) variant whose orientations are rotated around the film normal by $30^{\circ}$ each other. With increasing the Ni content ratio of $x$ from 0 to 1 , the volume ratio of two variants is varied from 53:47 to $94: 6$. The nucleation of only one-type variant with a smaller lattice mismatch with respect to $\mathrm{Cu}$ underlayer is promoted with increasing the $\mathrm{Ni}$ content ratio.
\end{abstract}

\section{Introduction}

$\mathrm{SmCo}_{5}$ alloy with $R T_{5}\left(D 2_{\mathrm{d}}\right)$ ordered structure shows $K_{\mathrm{u}}$ of $1.1 \times 10^{8} \mathrm{erg} / \mathrm{cm}^{3}$ [1] and the thin films with the $c$-axis perpendicular to the substrate surface have been investigated for applications like future recording media with the areal density exceeding $1 \mathrm{~Tb} / \mathrm{in}^{2} . \mathrm{SmCo}_{5}$ polycrystalline [2-7] and epitaxial [8-10] films of (0001) orientation have been prepared on $\mathrm{Cu}[2-5,8,9], \mathrm{Cu} / \mathrm{Ti}$ [4,5], $\mathrm{Ru} / \mathrm{Cu} / \mathrm{Ru}$ [6], $\mathrm{Ru}$ [7,10], and $\mathrm{Ru}-\mathrm{Cr}$ [7] underlayers. Most of the samples include a $\mathrm{Cu}$ underlayer. It is reported that $\mathrm{Cu}$ atoms of underlayer diffuse into an $\mathrm{Sm}-\mathrm{Co}$ film and partially substitute the Co site in $\mathrm{SmCo}_{5}$ structure forming an alloy compound of $\mathrm{Sm}(\mathrm{Co}, \mathrm{Cu})_{5}$ $[4,5]$. The dissolution of $\mathrm{Cu}$ atom into Sm-Co alloy is known to stabilize $R T_{5}$ structure [11-13].

The Co site in $\mathrm{SmCo}_{5}$ structure can be replaced with a $3 d$ ferromagnetic transition metal element of $T=\mathrm{Ni}$ [14]. The crystallization temperature and the film structure are considered to vary depending on the $T$ element. Ni $\left(1455^{\circ} \mathrm{C}\right)$ has a lower melting point than Co $\left(1495{ }^{\circ} \mathrm{C}\right)$. $\mathrm{Ni}$ atoms are thus considered to diffuse more easily and to have a lower activation energy in forming the $\operatorname{Sm} T_{5}$ compound. In our previous studies [8,9], $\mathrm{SmCo}_{5}$ epitaxial films were prepared on $\mathrm{Cu}(111)$ underlayers by employing a molecular beam epitaxy (MBE) system equipped with a reflection high-energy electron diffraction (RHEED) facility. In-situ observations revealed the crystallographic property during film formation. In the present study, $\mathrm{Sm}_{17}(\mathrm{Co}, \mathrm{Ni})_{83}$ and $\mathrm{Sm}_{17} \mathrm{Ni}_{83}$ (at. \%) films are deposited on $\mathrm{Cu}(111)$ underlayers in addition to $\mathrm{Sm}_{17} \mathrm{Co}_{83}$ films. The effects of $\mathrm{Ni} / \mathrm{Co}$ composition and substrate temperature on the ordered phase formation are investigated.

\section{Experimental procedure}

Thin films were prepared on $\mathrm{MgO}(111)$ substrates at temperatures ranging from 100 to $500{ }^{\circ} \mathrm{C}$ by using an MBE system with the base pressures lower than $7 \times 10^{-9}$ $\mathrm{Pa}$. Substrates were heated at $500{ }^{\circ} \mathrm{C}$ for $1 \mathrm{~h}$ before film formation to obtain clean surfaces. $\mathrm{Co}, \mathrm{Co}_{80} \mathrm{Ni}_{20}, \mathrm{Co}_{20} \mathrm{Ni}_{80}$ alloy, and $\mathrm{Ni}$ materials were evaporated by electron beam heating, whereas $\mathrm{Sm}$ and $\mathrm{Cu}$ were evaporated by using Knudsen cells. The purities of evaporation sources were higher than $99.9 \%$. The film layer structure is $\mathrm{Sm}_{17}\left(\mathrm{Co}_{1-x} \mathrm{Ni}_{x}\right)_{83}(20 \mathrm{~nm}) / \mathrm{Cu}(20 \mathrm{~nm}) / \mathrm{MgO}$. A 20-nmthick $\mathrm{Cu}$ underlayer and a 20 -nm-thick $\mathrm{Sm}_{17}\left(\mathrm{Co}_{1-x} \mathrm{Ni}_{x}\right)_{83}$ $(x=0,0.2,0.8,1)$ films were sequentially deposited on the substrate. The epitaxial orientation relationship of $\mathrm{Cu}$ underlayer with respect to substrate [8,9] was $\mathrm{Cu}(111)[1 \overline{1} 0],[\overline{1} 10] \| \operatorname{MgO}(111)[1 \overline{1} 0]$. The $\mathrm{Cu}$ underlayer consisted of two epitaxial fcc(111) variants whose atomic stacking sequences of close-packed plane along the perpendicular direction were $\mathrm{ABCABC} .$. and ACBACB... The $\mathrm{Sm}_{17}\left(\mathrm{Co}_{1-x} \mathrm{Ni}_{x}\right)_{83}$ film was deposited by co-evaporation of $\mathrm{Sm}$ and $\mathrm{Co}_{100(1-x)} \mathrm{Ni}_{100 x}$ materials. The compositions of $\mathrm{Sm}_{17}\left(\mathrm{Co}_{1-x} \mathrm{Ni}_{x}\right)_{83}$ films were confirmed by energy dispersive $\mathrm{X}$-ray spectroscopy and the errors were less than 2 at. $\%$ from the $\operatorname{Sm}\left(\mathrm{Co}_{1-x} \mathrm{Ni}_{x}\right)_{5}$ stoichiometries.

The surface structure during film deposition was studied by RHEED. The resulting film structure was investigated by $2 \theta / \omega$-scan out-of-plane, $2 \theta \chi / \varphi$-scan inplane, and $\beta$-scan pole-figure X-ray diffractions (XRDs) with $\mathrm{Cu}-\mathrm{K} \alpha$ radiation $(\lambda=0.15418 \mathrm{~nm})$. 

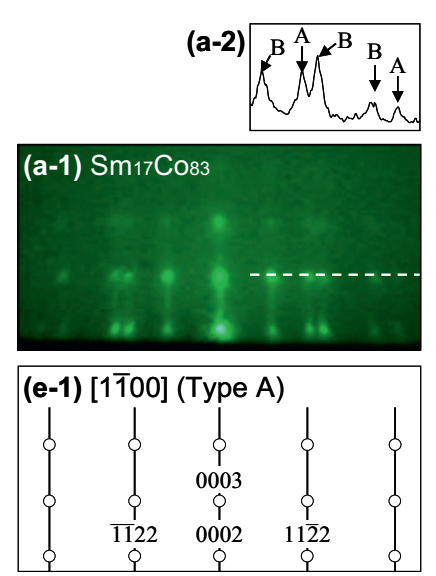

(b-2)
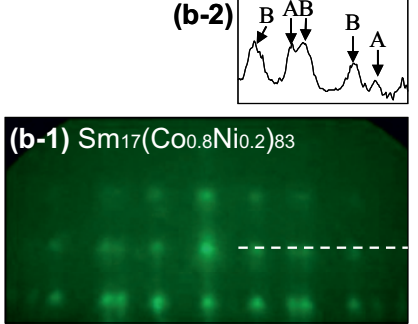

(e-2) [11̄̄0] (Type B)

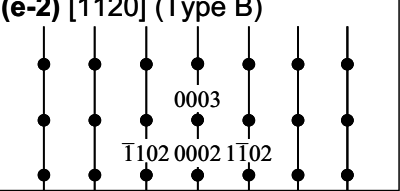

(c-2)
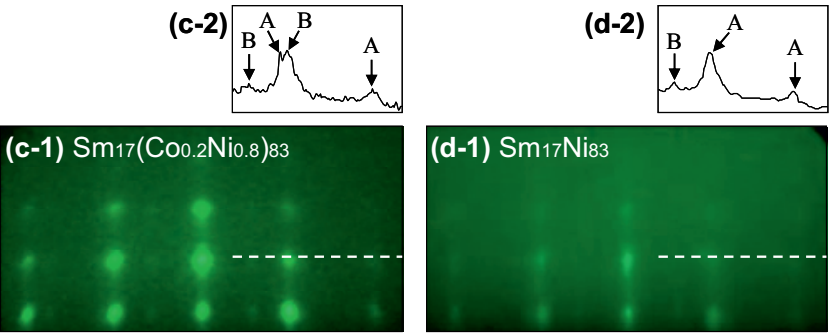

(e-3) Type A\&B [1T00]\&[11̄̄20]

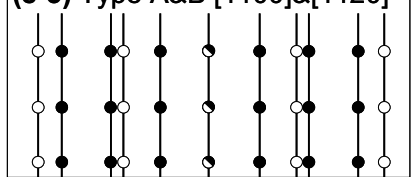

Fig. 1. (a-1)-(d-1) RHEED patterns and (a-2)-(d-2) the schematic diagrams of (a) $\mathrm{Sm}_{17} \mathrm{Co}_{83}$, (b) $\mathrm{Sm}_{17}\left(\mathrm{Co}_{0.8} \mathrm{Ni}_{02}\right)_{83}, \quad(\mathrm{c})$ $\mathrm{Sm}_{17}\left(\mathrm{Co}_{0.2} \mathrm{Ni}_{0.8}\right)_{83}$, and (d) $\mathrm{Sm}_{17} \mathrm{Ni}_{83}$ films of $20 \mathrm{~nm}$ thickness deposited on $\mathrm{Cu}(111)$ underlayers at $500{ }^{\circ} \mathrm{C}$. The profiles of (a-2)-(d-2) are measured along the dotted lines in (a-1)-(d-1). (e) Schematic diagrams of RHEED patterns simulated for (0001) surfaces with $R T_{5}$ ordered structure. The incident electron beam is parallel to (a)-(d) $\mathrm{MgO}[11 \overline{2}]$, (e-1) [1100], or (e-2) [1120].
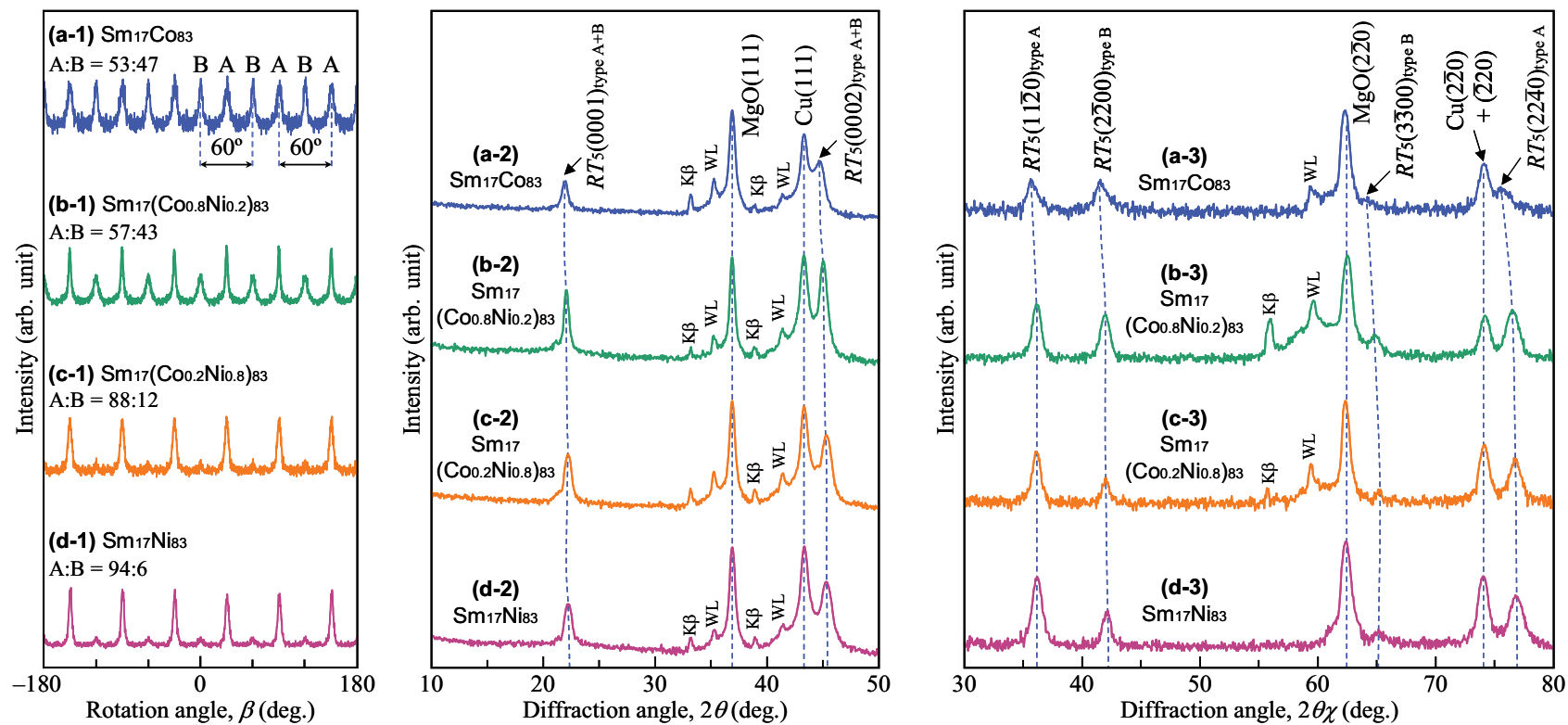

Fig. 2. (a-1)-(d-1) Pole-figure, (a-2)-(d-2) out-of-plane, and (a-3)-(d-3) in-plane XRD patterns of (a-1)-(a-3) $\mathrm{Sm}_{17} \mathrm{Co}_{83}$, (b-1)-(b-3) $\mathrm{Sm}_{17}\left(\mathrm{Co}_{0.8} \mathrm{Ni}_{0.2}\right)_{83}$, (c-1)-(c-3) $\mathrm{Sm}_{17}\left(\mathrm{Co}_{0.2} \mathrm{Ni}_{0.8}\right)_{83}$, and (d-1)-(d-3) $\mathrm{Sm}_{17} \mathrm{Ni}_{83}$ films deposited on $\mathrm{Cu}(111)$ underlayers at $500{ }^{\circ} \mathrm{C}$. The pole-figure patterns are measured by fixing the tilt and diffraction angles of $(\alpha, 2 \theta B)$ at $\left(47^{\circ}, 30.5^{\circ}\right)$. The in-plane patterns are measured by making the scattering vector parallel to $\mathrm{MgO}[110]$. The intensity is shown in (a-1)-(d-1) a linear scale or (a-2)-(d-3) a logarithmic scale. The small reflections noted as $\mathrm{K} \beta$ and $\mathrm{WL}$ are due to $\mathrm{Cu}-\mathrm{K} \beta$ and $\mathrm{W}-\mathrm{L} \alpha$ radiations included in the $\mathrm{X}$-ray source, respectively.

\section{Results and discussion}

The effects of $\mathrm{Co} / \mathrm{Ni}$ composition on the growth behaviour and the film structure were investigated. Here, the substrate temperature was fixed at $500{ }^{\circ} \mathrm{C}$. Figures 1(a-1)-(d-1) show the RHEED patterns of $\mathrm{Sm}_{17}\left(\mathrm{Co}_{1-x} \mathrm{Ni}_{x}\right)_{83}$ films deposited on $\mathrm{Cu}(111)$ underlayers observed by making the incident electron beam parallel to $\mathrm{MgO}[11 \overline{2}](\| \mathrm{Cu}[11 \overline{2}],[\overline{11} 2])$. Clear diffraction patterns corresponding to $R T_{5}(0001)$ texture [figure $1(\mathrm{e}-3)$ ] are observed for all the films. Epitaxial $\mathrm{Sm}_{17}\left(\mathrm{Co}_{1-x} \mathrm{Ni}_{x}\right)_{83}$ films with $R T_{5}$ ordered structure and with the $c$-axis perpendicular to the substrate surface are obtained. The diffraction patterns are analyzed to be an overlap of two reflections [figures $1(\mathrm{e}-1, \mathrm{e}-2)$ ], as shown by the arrows $\mathrm{A}$ and $B$ in the intensity profiles of figures (a-2)-(d-2). The epitaxial orientation relationship is thus determined as follows,

$$
\begin{aligned}
& \mathrm{Sm}_{17}\left(\mathrm{Co}_{1-x} \mathrm{Ni}_{x}\right)_{83}(0001)[1 \overline{1} 00] \\
& \| \mathrm{Cu}(111)[11 \overline{2}],[\overline{11} 2] \text { (type A), } \\
& \mathrm{Sm}_{17}\left(\mathrm{Co}_{1-x} \mathrm{Ni}_{x}\right)_{83}(0001)[11 \overline{2} 0]
\end{aligned}
$$$$
\| \mathrm{Cu}(111)[11 \overline{2}],[\overline{11} 2] \text { (type B). }
$$

The films consist of two types of (0001) variant whose orientations are rotated around the film normal by $30^{\circ}$ each other.

In these configuration, the lattice misfit values of Atype $\mathrm{Sm}_{17} \mathrm{Co}_{83}, \mathrm{Sm}_{17}\left(\mathrm{Co}_{0.8} \mathrm{Ni}_{0.2}\right)_{83}, \mathrm{Sm}_{17}\left(\mathrm{Co}_{0.2} \mathrm{Ni}_{0.8}\right)_{83}$, and $\mathrm{Sm}_{17} \mathrm{Ni}_{83}$ variants with respect to $\mathrm{Cu}$ underlayer are $-2.5 \%,-2.8 \%,-3.4 \%$, and $-3.6 \%$, while those of B-type variants are $+12.5 \%,+12.3 \%,+11.5 \%$, and $+11.3 \%$. Here, the lattice constants of bulk $\operatorname{SmCo}_{5}\left(a_{\mathrm{SmCo5}}=0.4982 \mathrm{~nm}\right.$ [15]), $\quad \mathrm{SmNi}_{5} \quad\left(a_{\mathrm{SmNi}}=0.4926 \mathrm{~nm}\right.$ [16] $)$, and $\mathrm{Cu}\left(a_{\mathrm{Cu}}=0.3615 \mathrm{~nm}\right.$ [17] $)$ crystals and the lattice constants of $a_{\mathrm{SmCo} 4 \mathrm{Ni}}\left(=0.8 a_{\mathrm{SmCo5}}+0.2 a_{\mathrm{SmNi5}}\right)$ and $a_{\mathrm{SmCoNi4}}$ $\left(=0.2 a_{\mathrm{SmCo5}}+0.8 a_{\mathrm{SmNi5}}\right)$, which are estimated by using the 
lattice constants of $a_{\mathrm{SmCo5}}$ and $a_{\mathrm{SmNi}}$, are used. Although there are fairly large mismatches in the cases of B-type variants, epitaxial growth is taking place. With increasing the Ni composition, the intensity of RHEED reflection from B-type variant becomes weaker, as shown in figures $1(\mathrm{a}-2)-(\mathrm{d}-2)$. In order to investigate the volume ratio of two types of variant, pole-figure XRD was carried out. Figures 2 (a-1)-(d-1) show the $\beta$-scan pole-figure XRD patterns measured by fixing the tilt and diffraction angles of $(\alpha, 2 \theta B)$ at $\left(47^{\circ}, 30.5^{\circ}\right)$, where $R T_{5}\{1 \overline{1} 01\}$ reflections are expected to be detectable. For all the films, twelve $R T_{5}\{1 \overline{1} 01\}$ reflections, which originate from the two types of variant, are observed with $30^{\circ}$ separation. The volume ratios of A-type to B-type variant involved in $\mathrm{Sm}_{17} \mathrm{Co}_{83}, \quad \mathrm{Sm}_{17}\left(\mathrm{Co}_{0.8} \mathrm{Ni}_{0.2}\right)_{83}, \quad \mathrm{Sm}_{17}\left(\mathrm{Co}_{0.2} \mathrm{Ni}_{0.8}\right)_{83}, \quad$ and $\mathrm{Sm}_{17} \mathrm{Ni}_{83}$ films are estimated from the integrated intensities of $\{1 \overline{1} 01\}$ reflection of each variant to be $53: 47, \quad 57: 43,88: 12$, and 94:6, respectively. The nucleation of only A-type variant is apparently enhanced with increasing the Ni content.

Figures 2(a-2)-(d-2) show the out-of-plane XRD patterns of $\mathrm{Sm}_{17}\left(\mathrm{Co}_{1-x} \mathrm{Ni}_{x}\right)_{83}$ films. $R T_{5}(0001)$ superlattice reflections are clearly observed in addition to $R T_{5}(0002)$ fundamental reflections for all the films. The out-of-plane XRD confirms the formation of $R T_{5}$ ordered phase. Longrange order degree $(S)$ is estimated by comparing the intensity ratio of $R T_{5}(0001)$ superlattice to $R T_{5}$ fundamental reflection. The intensity $(I)$ is proportional to structure $\left(F F^{*}\right)$, Lorentz-polarization $(L)$, and absorption (A) [18]. Here, $I$ is a product of integrated intensity multiplied by the full with at half maximum of rocking curve measured for the reflection. In the present paper, an influence of temperature factor, which is often omitted when comparing two reflection intensities, is not considered. $F_{\mathrm{s}}$ and $F_{\mathrm{f}}$ are respectively $S\left[f_{\mathrm{Sm}}-\left\{(1-x) f_{\mathrm{Co}}+x f_{\mathrm{Ni}}\right\}\right]$ and $f_{\mathrm{Sm}}+5\left\{(1-x) f_{\mathrm{Co}}+x f_{\mathrm{Ni}}\right\} \quad$ [19], where $f$ is the atomic scattering factor of $\mathrm{Sm}, \mathrm{Co}$, or $\mathrm{Ni}$ and the subscripts of $\mathrm{s}$ and $\mathrm{f}$ refer to the superlattice and fundamental reflections, respectively. Therefore, $I_{\mathrm{S}} / I_{\mathrm{f}}$ is expressed as

$$
\begin{aligned}
I_{(0001)} / I_{(0002)}=\left[\left\{S\left[f_{\mathrm{Sm}}-\left\{(1-x) f_{\mathrm{Co}}+x f_{\mathrm{Ni}}\right\}\right]\right\}^{2} L A\right]_{\mathrm{s}} \\
/\left[f_{\mathrm{Sm}}+5\left\{(1-x) f_{\mathrm{Co}}+x f_{\mathrm{Ni}}\right\}^{2} L A\right]_{\mathrm{f} .}
\end{aligned}
$$

By solving this equation, $S$ is given as

$$
\begin{aligned}
& S=\left(I_{\mathrm{s}} / I_{\mathrm{f}}\right) \times\left\{\left[f_{\mathrm{Sm}}+5\left\{(1-x) f_{\mathrm{Co}}+x f_{\mathrm{Ni}}\right\}\right]_{\mathrm{f}} /\right. \\
& \left.\left[f_{\mathrm{Sm}}-\left\{(1-x) f_{\mathrm{Co}}+x f_{\mathrm{Ni}}\right\}\right]_{\mathrm{s}}\right\} \times\left[\{L A\}_{\mathrm{f}} /\{L A\}_{\mathrm{s}}\right]^{1 / 2} .
\end{aligned}
$$

The $S$ values of $\mathrm{Sm}_{17} \mathrm{Co}_{83}, \quad \mathrm{Sm}_{17}\left(\mathrm{Co}_{0.8} \mathrm{Ni}_{0.2}\right)_{83}$, $\mathrm{Sm}_{17}\left(\mathrm{Co}_{0.2} \mathrm{Ni}_{0.8}\right)_{83}$, and $\mathrm{Sm}_{17} \mathrm{Ni}_{83}$ films are $0.77,0.82,0.89$, and 0.97 , respectively. The $S$ value is improved with increasing the $\mathrm{Ni}$ content and the $\mathrm{Sm}_{17} \mathrm{Ni}_{83}$ film is almost fully ordered.

Figures 2(a-3)-(d-3) shows the in-plane XRD patterns measured by making the scattering vector parallel to $\mathrm{MgO}[1 \overline{1} 0] . R T_{5}(11 \overline{2} 0)$ and $R T_{5}(22 \overline{4} 0)$ reflections from Atype variant and $R T_{5}(2 \overline{2} 00)$ and $R T_{5}(3 \overline{3} 00)$ reflections from B-type variant are recognized. The in-plane XRD confirms the epitaxial orientation relationship determined by RHEED. The lattice constants of A- and B-type variants, $\left(a_{\text {type A }}, a_{\text {type B }}\right)=\left(2 d_{(11 \overline{2} 0)}, 4 /\left(3^{1 / 2}\right) d_{(2 \overline{2} 00)}\right)$, included in $\mathrm{Sm}_{17} \mathrm{Co}_{83}, \mathrm{Sm}_{17}\left(\mathrm{Co}_{0.8} \mathrm{Ni}_{0.2}\right)_{83}, \mathrm{Sm}_{17}\left(\mathrm{Co}_{0.2} \mathrm{Ni}_{0.8}\right)_{83}$, and $\mathrm{Sm}_{17} \mathrm{Ni}_{83}$ films are calculated from the in-plane XRD data to be $(0.5041 \mathrm{~nm}, 0.5021 \mathrm{~nm}),(0.4978 \mathrm{~nm}, 0.4972 \mathrm{~nm})$, $(0.4966 \mathrm{~nm}, 0.4968 \mathrm{~nm})$, and $(0.4964 \mathrm{~nm}, 0.4959 \mathrm{~nm})$, respectively. The lattice constants, $c_{\text {type } \mathrm{A}+\mathrm{B}}=d_{(0001)}$, of $\mathrm{Sm}_{17} \mathrm{Co}_{83}, \quad \mathrm{Sm}_{17}\left(\mathrm{Co}_{0.8} \mathrm{Ni}_{0.2}\right)_{83}, \quad \mathrm{Sm}_{17}\left(\mathrm{Co}_{0.2} \mathrm{Ni}_{0.8}\right)_{83}, \quad$ and $\mathrm{Sm}_{17} \mathrm{Ni}_{83}$ films are estimated from the out-of-plane XRD data to be $0.4054 \mathrm{~nm}, 0.4026 \mathrm{~nm}, 0.4005 \mathrm{~nm}$, and 0.4001 $\mathrm{nm}$, respectively. The lattice constants, $a_{\mathrm{type} \mathrm{A}}, a_{\mathrm{type} \mathrm{B}}, c$, of respective films are slightly larger than those of bulk $\mathrm{SmCo}_{5}\left(a_{\mathrm{SmCo5}}=0.4982 \mathrm{~nm}, c_{\mathrm{SmC} 5}=0.3975 \mathrm{~nm}[15]\right)$, $\mathrm{SmCo}_{4} \mathrm{Ni}\left(a_{\mathrm{SmCo} 4 \mathrm{Ni}}=0.4971 \mathrm{~nm}, c_{\mathrm{SmCo} 4 \mathrm{Ni}}=0.3976 \mathrm{~nm}\right)$, $\mathrm{SmCoNi}_{4}\left(a_{\mathrm{SmCoNi}}=0.4937 \mathrm{~nm}, c_{\mathrm{SmCoNi}}=0.3979 \mathrm{~nm}\right)$, and $\operatorname{SmNi}_{5}\left(a_{\mathrm{SmNi5}}=0.4926 \mathrm{~nm}, c_{\mathrm{SmNi5}}=0.3980 \mathrm{~nm}\right.$ [16] $)$ crystals and smaller than that of bulk $\operatorname{SmCu}_{5}\left(a_{\mathrm{SmCu} 5}=\right.$ $0.507 \mathrm{~nm}, c_{\mathrm{SmCu} 5}=0.410 \mathrm{~nm}$ [20]) crystal. The $T$ site in $\mathrm{Sm}\left(\mathrm{Co}_{1-x} \mathrm{Ni}_{x}\right)_{5}$ structure may be partially replaced with $\mathrm{Cu}$ atoms with larger atomic radius. There is thus a possibility that $\mathrm{Cu}$ atoms of underlayer diffuse into the $\mathrm{Sm}_{17}\left(\mathrm{Co}_{1-x} \mathrm{Ni}_{x}\right)_{83}$ film and an alloy compound of $\mathrm{Sm}\left(\mathrm{Co}_{1-x} \mathrm{Ni}_{x}, \mathrm{Cu}\right)_{5}$ is formed, similar to the case of $\mathrm{SmCo}_{5}$ films formed on $\mathrm{Cu}$ underlayers $[2-5,8,9]$.

In order to study the effect of substrate temperature on the ordered phase formation, $\mathrm{Sm}_{17}\left(\mathrm{Co}_{1-x} \mathrm{Ni}_{x}\right)_{83}$ films were deposited at temperatures ranging from 100 to $500{ }^{\circ} \mathrm{C}$. Figures 3(a)-(d) show the RHEED patterns observed during formation of $\mathrm{Sm}\left(\mathrm{Co}_{1-x} \mathrm{Ni}_{x}\right)_{5}$ films at different temperatures. As the substrate temperature and the $\mathrm{Ni}$
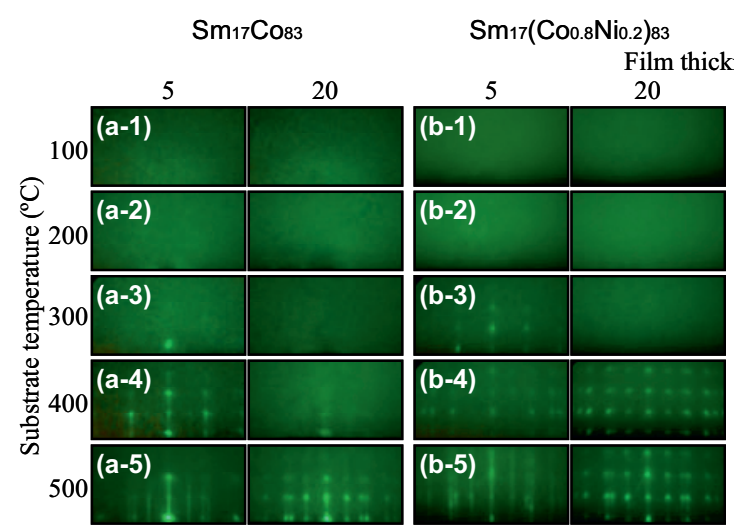

$\mathrm{Sm}_{17}\left(\mathrm{Co}_{2.2 \mathrm{Ni} 0.8}\right)_{83}$

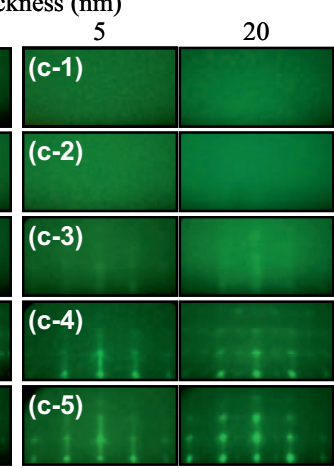

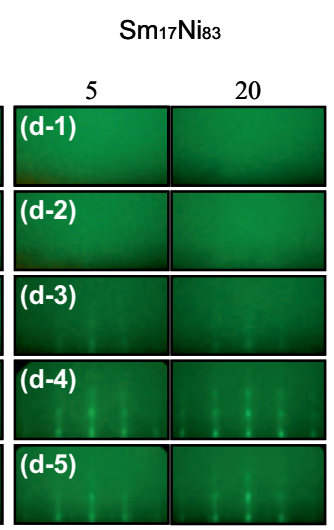

Fig. 3. RHEED patterns observed during formation of (a-1)-(a-5) $\mathrm{Sm}_{17} \mathrm{Co}_{83}$, (b-1)-(b-5) $\mathrm{Sm}_{17}\left(\mathrm{Co}_{0.2} \mathrm{Ni}_{0.8}\right)_{83}$, (c-1)-(c-5) $\mathrm{Sm}_{17}\left(\mathrm{Co}_{0.8} \mathrm{Ni}_{0.2}\right)_{83},(\mathrm{~d}-1)-(\mathrm{d}-5) \mathrm{Sm}_{17} \mathrm{Ni}_{83}$ films on $\mathrm{Cu}(111)$ underlayers at (a-1)-(d-1) 100, (a-2)-(d-2) 200, (a-3)-(d-3) 300, (a-4)-(d-4) 400 , and $(\mathrm{a}-5)-(\mathrm{d}-5) 500{ }^{\circ} \mathrm{C}$, respectively. The incident electron beam is parallel to $\mathrm{MgO}[11 \overline{2}]$. Phase transformation maps of (a-6) $\mathrm{Sm}_{17} \mathrm{Co}_{83}$, (b-6) $\mathrm{Sm}_{17}\left(\mathrm{Co}_{0.2} \mathrm{Ni}_{0.8}\right)_{83}$, (c-6) $\mathrm{Sm}_{17}\left(\mathrm{Co}_{0.8} \mathrm{Ni}_{0.2}\right)_{83}$, and (d-6) $\mathrm{Sm}_{17} \mathrm{Ni}_{83}$ films. 


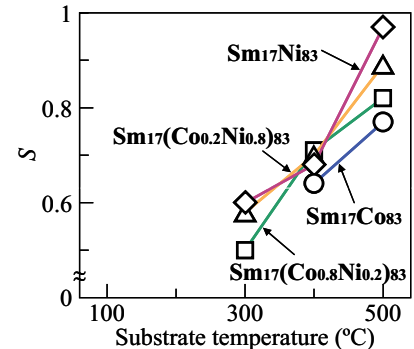

Fig. 4. Substrate temperature dependences on long range ordering parameter, $S$ value, measured for $\mathrm{Sm}_{17}\left(\mathrm{Co}_{1-x} \mathrm{Ni}_{x}\right)_{83}$ films.

content decrease from $500{ }^{\circ} \mathrm{C}$ and $x=1$, the sharpness of RHEED pattern gradually decreases with overlapping diffuse contrast. The variation suggests that amorphous phase is appearing. The transformations from crystalline to amorphous phase as functions of film thickness and temperature are summarized in Figs. 3(a-6)-(d-6). The crystallization temperature apparently decreases with increasing the $\mathrm{Ni}$ content. The result is possibly due to a lower activation energy of $\mathrm{Ni}$ in forming the $\mathrm{Sm} T_{5}$ compound. Figure 4 shows the substrate temperature dependences of $S$ of $\mathrm{Sm}_{17}\left(\mathrm{Co}_{1-x} \mathrm{Ni}_{x}\right)_{83}$ films. The $S$ value increases with increasing not only the substrate temperature but also the $\mathrm{Ni}$ content. A replacement of $\mathrm{Co}$ site in $\mathrm{SmCo}_{5}$ structure with $\mathrm{Ni}$ atom is useful for enhancing the $R T_{5}$ ordered phase formation.

\section{Conclusion}

$\mathrm{Sm}_{17}\left(\mathrm{Co}_{1-x} \mathrm{Ni}_{x}\right)_{83}$ films are deposited on $\mathrm{Cu}(111)$ underlayers by varying the $\mathrm{Ni}$ content of $x$ from 0 to 1 and by varying the substrate temperature from 100 to $500{ }^{\circ} \mathrm{C}$. The film growth behavior and the detailed films structure are investigated by RHEED and XRD. With increasing the substrate temperature and the Ni content, formation of $R T_{5}$ ordered phase is promoted. The $S$ values of $\mathrm{Sm}_{17} \mathrm{Co}_{83}, \mathrm{Sm}_{17}\left(\mathrm{Co}_{0.8} \mathrm{Ni}_{0.2}\right)_{83}, \mathrm{Sm}_{17}\left(\mathrm{Co}_{0.2} \mathrm{Ni}_{0.8}\right)_{83}$, and $\mathrm{Sm}_{17} \mathrm{Ni}_{83}$ films are $0.77,0.82,0.89$, and 0.97 , respectively. A replacement of $\mathrm{Co}$ site in $\mathrm{SmCo}_{5}$ structure with $\mathrm{Ni}$ atom is useful for enhancing the $R T_{5}$ ordered phase formation. The $\mathrm{Sm}_{17}\left(\mathrm{Co}_{1-x} \mathrm{Ni}_{x}\right)_{83}$ films consist of two types of (0001) variant. As the Ni content of $x$ increases from 0 to 1 , the volume ratio of two variants varies from 53:47 to 94:6. The epitaxial growth of only one-type variant with a smaller lattice mismatch with respect to $\mathrm{Cu}$ underlayer is enhanced with increasing the $\mathrm{Ni}$ content.

\section{Acknowledgements}

A part of this work was supported by JSPS KAKENHI Grant Number 25420294, JST A-STEP Grant Number AS242Z00169M, and Chuo University Grant for Special Research.

\section{References}

1. K. J. Strnat, Handbook of Ferromagnetic Materials (Elsevier Science B. V., New York, 1988)

2. J, Sayama, T. Asahi, K. Mizutani, T. Osaka, J. Phys. D 37, L1 (2004)

3. S. Takei, A. Morisako, M. Matsumoto, J. Magn. Magn. Mater. 272-276, 1703 (2004)

4. J. Sayama, K. Mizutani, T. Ariake, K. Ouchi, T. Osaka, J. Magn. Magn. Mater. 301, 271 (2006)

5. Y. K. Takahashi, T. Ohkubo, K. Hono, J. Appl. Phys. 100, 053913 (2006)

6. I. Kato, S. Takei, X. Liu, A. Morisako, IEEE Trans. Magn. 42, 2366 (2006)

7. X. Liu, H. Zhao, Y. Kubota, J. -P. Wang, J. Phys. D 41, 232002 (2008)

8. Y. Nukaga, M. Ohtake, F. Kirino, M. Futamoto, IEEE Trans. Magn. 44, 2891 (2008)

9. M. Ohtake, Y. Nukaga, F. Kiriono, M. Futamoto, J. Cryst. Growth 311, 2251 (2009)

10. M. Seifert, V. Neu, L. Schultz, Appl. Phys. Lett. 94, 022501 (2009)

11. F. Hofer, IEEE Trans. Magn. 6, 221 (1970)

12. K. Kamino, Y. Kimura, T. Suzuki, Y. Itayama, Trans. Jpn. Inst. Met. 14, 135 (1973)

13. A. J. Perry, J. Less-Common Met. 51, 153 (1977)

14. H. Okamoto, T. B. Massalski, Binary Alloy Phase Diagrams (ASM International, Ohio, 1990)

15. H. Ido, M. Nanjo, M. Yamada, J. Appl. Phys. 75 , 7140 (1994)

16. A. Pasturel, C. Colinet, C. H. Allibert, P. Hicter, A. G. Percheron, J. C. Achard, Phys. Status Solidi B 125, 101 (1984)

17. R. P. van Ingen, R. H. J. Fastenau, E. J. Mittemeijer, J. Appl. Phys. 76, 1871 (1994)

18. B. D. Cullity, Elements of X-Ray Diffraction (Addison-Wesley, Massachusetts, 1956)

19. T. Yanagawa, M. Ohtake, F. Kirino, M. Futamoto, EPJ Web Conf. 40, 06007 (2013)

20. S. Derkaoui, C. H. Allibert, J. Less-Common Met. 154, 309 (1989) 